\title{
THE LUNG VOLUME AND ITS SUBDIVISIONS
}

\section{METHODS OF MEASUREMENT}

\author{
BY RONALD V. CHRISTIE
}

(From the Department of Medicine, McGill University Clinic, Royal Victoria Hospital, Montreal)

(Received for publication June 21, 1932)

In perhaps no realm of physiology is there a more confusing medley of terms than in that which deals with the lung volume and its various subdivisions. Not only does the meaning of many terms vary with the user but there is an unfortunate superfluity and synonymity of the terms themselves.

Residual air as first described by Davy (1800) is the amount of air remaining in the lungs after the fullest possible expiration.

Vital capacity as described by Hutchinson (1846) is the amount of air that can be expired from the fullest inspiration to the fullest expiration.

Total lung volume or total capacity is the sum of residual air and the vital capacity.

Mid-capacity as defined by Panum (1868) is the amount of air in the lungs at a point mid-way between normal inspiration and expiration, this level being referred to as the mid-position or mid-point, or even vital respiratory level. Siebeck (1910) and others prefer to describe the mid-capacity as a quantity synonymous with the functional residual air (vide infra).

Functional residual air as described by Lundsgaard and Schierbeck (1923) is that amount of air remaining in the lungs after a normal expiration. This quantity has also been called the mid-capacity or normal capacity, and the level has been named the resting respiratory level, the expiratory level, the mid-position or mid-point.

Complemental air has been variously described as the amount of air inspired from the mid-position to maximum inflation, or from the height of a normal inspiration to maximum inflation.

Reserve air or supplemental air has been variously described as the air expired from the mid-position to maximum deflation or from the end of a normal expiration to maximum deflation.

Tidal air is the quantity of air expired by a breath of average depth.

Were it not for the confusion that already exists we would hesitate to offer any further addition to this classification but simplification necessarily involves some minor changes in definitions. The terms vital capacity and residual air have stood the test of time and we would not modify them. However, they are the product of respiratory gymnastics and surely it is important to establish some simple nomenclature with respect to the level at which we normally breathe. A glance at any 
series of respiratory tracings, as taken in the routine estimation of the basal metabolic rate, shows clearly that the constant respiratory level is at the end of expiration. The inspiratory level and mid-capacity vary with the depth of inspiration, a variation which is of ten considerable both from breath to breath and from minute to minute. From a functional point of view also, it is the amount of air remaining in the lungs after expiration (the functional residual air) that we have to ventilate. Without entering into a discussion of the Hering Breuer reflex it can be safely said that there is much evidence that it is from the expiratory level (resting respiratory level) that the respiratory cycle has its initiation. Also it is at this level that there occurs the maximum pause during the respiratory cycle. To inflate the lungs above it one group of muscles is used, while to deflate the lungs below it an entirely different group is used. It would seem then that, from both practical and theoretical considerations, any measurements involving the amount of air normally present in the lungs should be based on the functional residual air or the resting respiratory level. On this basis we have adopted the nomenclature depicted in Figure 1. The complemental and reserve airs are

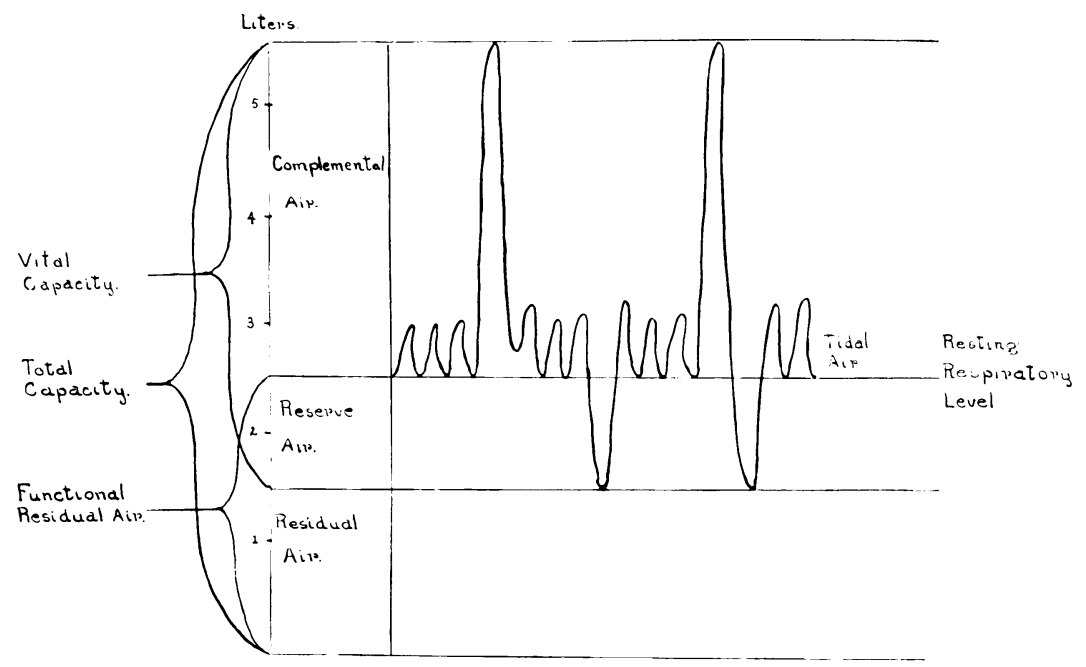

Fig. 1. The Lung Volume and Its Subdivisions

measured from the resting respiratory level and we agree with Anthony (1927 and 1930) that these should be measured separately, but are equally convinced that the vital capacity should also be measured independently, as in its original definition by Hutchinson. The reasons for this are obvious when we consider those cases where there is any impairment of pulmonary elasticity. Two tracings of the vital capacity in such a case are shown in Figure 2 and it is obvious that if we divide the vital capacity into complemental and reserve air we are confronted with 
the absurdity of having a negative quantity for the latter. Actually when the reserve air was measured separately in this case it amounted to some $300 \mathrm{cc}$. The significance of this type of tracing will be discussed in a subsequent communication but we believe that such a discrepancy between the sum of the complemental and reserve airs measured in this way, and the vital capacity, represents the earliest sign of impairment of pulmonary elasticity. This feature can only be brought out if the tracings are taken in the manner described.

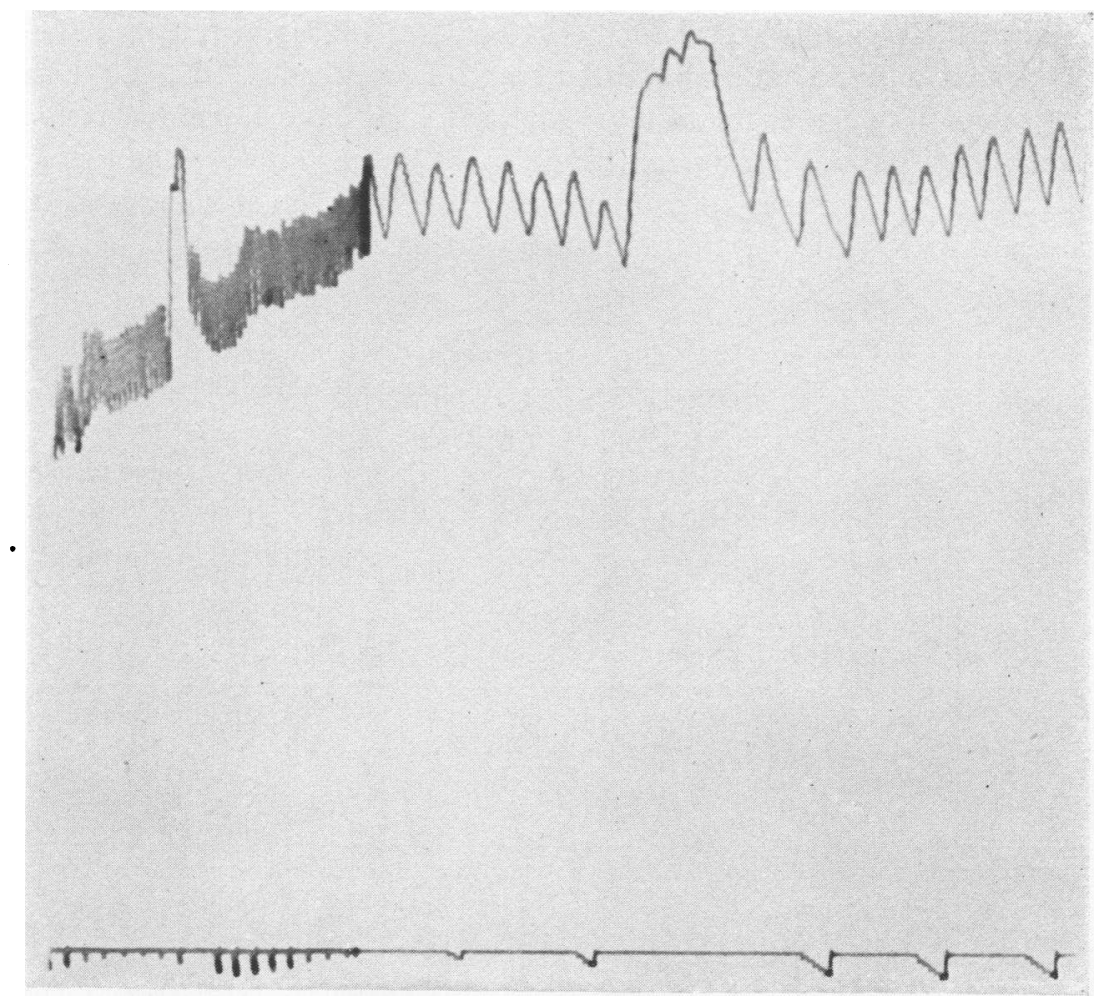

Fig. 2. The Vital Capacity in a Case of Advanced Emphysema Time marker 5 seconds.

By using this nomenclature a complete analysis of the lung volume and its functional and artificial subdivisions can be made, by stating only 5 quantities. (a) The complemental air, reserve air and vital capacity, (b) the tidal air, $(c)$ the residual or functional residual air. These three groups will be considered separately.

Measurement of the complemental air, reserve air and vital capacity

It is obvious that to measure the complemental and reserve air, some method involving the graphic registration of respiration must be used 
(Figure 1). By ordinary graphic spirometric methods the volume of air displaced by forced inspiration or expiration can be measured accurately to within 5 or $10 \mathrm{cc}$, and yet under even carefully controlled conditions we have found these amounts to vary by several hundred cc. in duplicate measurements on the same subject.

The expulsion of the reserve air is the result of a voluntary unnatural effort and as such can be profoundly influenced by many factors such as posture (Panum (1868), Bohr (1907), Hasselbach (1908), Wilson (1927) and Livingstone (1928)), fatigue (Peabody and Sturgis (1921)), respiratory resistance (Bittorf and Forschbach (1910), Bass (1925) and Thiel (1929)), and various external stimuli (Bittorf and Forschbach (1910)). Even when these factors were carefully excluded ${ }^{1}$ we have found variations of over $300 \mathrm{cc}$. in both normal and pathological subjects. The same range of variation was found in measurements of the complemental air and the vital capacity (Table I), and as no correlation could be found between

TABLE I

Variations in the vital capacity and its subdivisions

\begin{tabular}{|c|c|c|c|c|c|}
\hline $\begin{array}{l}\text { Quantity } \\
\text { measured }\end{array}$ & Group & $\begin{array}{c}\text { Number } \\
\text { of } \\
\text { cases }\end{array}$ & $\begin{array}{c}\text { Number } \\
\text { of } \\
\text { observations }\end{array}$ & $\begin{array}{c}\text { Average } \\
\text { deviation from } \\
\text { individual mean }\end{array}$ & $\begin{array}{l}\text { Maximum } \\
\text { deviation from } \\
\text { individual mean }\end{array}$ \\
\hline $\begin{array}{c}\text { Vital } \\
\text { capacity }\end{array}$ & $\begin{array}{l}\text { Normals..... } \\
\text { Emphysema . } \\
\text { Cardio- } \\
\text { respiratory. }\end{array}$ & $\begin{array}{r}4 \\
5 \\
10\end{array}$ & $\begin{array}{l}28 \\
19 \\
\\
33\end{array}$ & $\begin{array}{c}c c . \\
\pm 110 \\
\pm 89 \\
\pm 115\end{array}$ & $\begin{array}{c}c c . \\
314 \\
300 \\
403\end{array}$ \\
\hline Reserve air & $\begin{array}{l}\text { Normals ..... } \\
\text { Emphysema . } \\
\text { Cardio- } \\
\text { respiratory. }\end{array}$ & $\begin{array}{r}4 \\
5 \\
10\end{array}$ & $\begin{array}{l}37 \\
27 \\
37\end{array}$ & $\begin{array}{l} \pm 78 \\
\pm 76 \\
\pm 63\end{array}$ & $\begin{array}{l}318 \\
225 \\
371\end{array}$ \\
\hline $\begin{array}{l}\text { Comple- } \\
\text { mental } \\
\text { air }\end{array}$ & $\begin{array}{l}\text { Normals..... } \\
\text { Emphysema . } \\
\text { Cardio- } \\
\text { respiratory. }\end{array}$ & $\begin{array}{r}4 \\
5 \\
10\end{array}$ & $\begin{array}{l}32 \\
29 \\
40\end{array}$ & $\begin{array}{l} \pm 109 \\
\pm 62 \\
\pm 115\end{array}$ & $\begin{array}{l}316 \\
187 \\
350\end{array}$ \\
\hline
\end{tabular}

the variation of these three quantities and they do not permit of statistical analysis, one must conclude that they were due to fortuitous changes in muscular effort rather than changes in the resting respiratory level. Indeed this is the only possible explanation since any series of reserve and complemental air estimations made at say $\frac{1}{2}$ minute intervals show the same variations, although the resting respiratory level may remain a perfectly even base line. Such a variation in a voluntary and almost violent respiratory effort as is required for the complete expulsion of the

${ }^{1}$ Subject rested for 15 minutes in recumbent position, measurements then made with arms by side, shoulders flat on bed, and one pillow supporting head. 
reserve air or indraught of the complemental air is indeed to be expected from a general physiological point of view and necessarily reflects fortuitous variations in the residual air and total capacity.

\section{Measurement of the tidal air}

The measurement of the tidal air is a very simple physical problem and so many accurate methods have been described that any discussion would be pointless. The same may be said of any discussion of changes in the tidal air due to central and peripheral stimuli. It need only be emphasized that the tidal air is a quantity which varies from breath to breath and only an average over a stated period of time has any real meaning.

\section{Measurement of residual or functional residual air}

The number of methods described for the measurement of the residual or functional residual air approaches the number of papers published on this subject, a total of 47 having been reviewed. Although there are obvious fallacies in many of the methods and equally obvious incompatibilities in the results produced, we have been unable to find any critical review of the subject. Before describing the method which we have developed we propose to present some theoretical and experimental criticism of those methods commonly in use. These divide themselves into three main groups:

(1) The so-called pneumatometric method,

(2) Gas dilution with forced breathing,

(3) Gas dilution without forced breathing.

The principles underlying these methods will be criticised separately without entering into the minor modifications which have been proposed by almost every worker in this field.

\section{PNEUMATOMETRIC METHOD}

Originally described by Pflüger (1882) this method is based on Boyle's Law, which states that the volume of a gas varies in inverse proportion to the pressure to which it is subjected. The subject is placed in an airtight cabinet, breathing through a mask or mouthpiece connected with an opening in the cabinet. The air displaced from the cabinet by the respiratory expansion and contraction of the chest is graphically recorded by means of a spirometer. Expiration is suddenly completely obstructed and the subject told to make an expiratory or inspiratory effort against this absolute resistance. The positive or negative pressure so generated in the respiratory tract is recorded by a mercury manometer and the change in the volume of air in the lungs also accurately recorded by a small spirometer attached to the cabinet. From the relationship of the volume change to the pressure change the volume of air in the lungs can 


\begin{tabular}{|c|c|c|c|c|c|c|c|c|c|c|c|c|c|}
\hline & 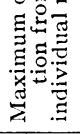 & $\dot{\Xi} \underset{N}{\stackrel{N}{N}}$ & 年 & 2 & $\stackrel{2}{\approx}$ & $\partial े$ & $\underset{-}{+}$ & $\stackrel{\circ}{=}$ & in & 总 & 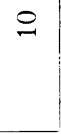 & $\underset{\sim}{\infty}$ & $\stackrel{8}{=}$ \\
\hline & 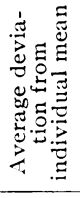 & $\dot{U}$ & $\stackrel{2}{\hat{H}}$ & $\begin{array}{l}\curvearrowright \\
+ \\
H\end{array}$ & $\frac{\mathbb{H}}{\mathrm{H}}$ & $\stackrel{+}{H}$ & n. & $\begin{array}{l}\infty \\
\infty \\
H\end{array}$ & $\stackrel{\text { P }}{+}$ & $\stackrel{N}{H}$ & it & $\stackrel{5}{\stackrel{5}{H}}$ & $\ddot{\hat{\theta}}$ \\
\hline 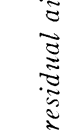 & $\stackrel{\Xi}{\Xi}$ & ن & $\ddot{\approx}$ & $\stackrel{0}{1}$ & $\stackrel{8}{8}$ & 点 & $\underset{i}{O}$ & $\stackrel{\infty}{\stackrel{一}{\sim}}$ & $\begin{array}{l}8 \\
\text { in } \\
2\end{array}$ & $\ddot{8}$ & $\frac{\theta}{\Rightarrow}$ & $\stackrel{\infty}{a}$ & 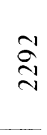 \\
\hline 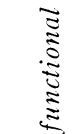 & $\stackrel{\Xi}{\Xi}$ & نُ & 옹 & 草 & 总 & $\underset{\widetilde{\sim}}{\stackrel{\sim}{\sim}}$ & $\begin{array}{l}\vec{x} \\
\underset{\Xi}{ \pm}\end{array}$ & $\begin{array}{l}3 \\
\approx\end{array}$ & 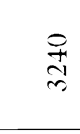 & 点 & $\underset{\frac{i}{i n}}{i s}$ & $\overrightarrow{\widetilde{q}}$ & $\underset{i}{\stackrel{2}{i}}$ \\
\hline 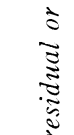 & 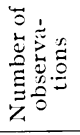 & 8 & F & $\stackrel{\partial}{-}$ & $\stackrel{\sim}{\sim}$ & $\stackrel{\infty}{=}$ & $\vec{n}$ & 10 & $\stackrel{\wedge}{\sim}$ & $\bar{i}$ & 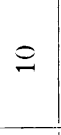 & f & $\stackrel{i}{\sim}$ \\
\hline $\begin{array}{r}\cong \\
=\frac{\Xi}{5} \\
\qquad \approx\end{array}$ & 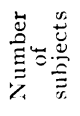 & - & 0 & in & $=$ & $\infty$ & in & - & $\cong$ & $a$ & 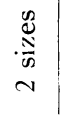 & \pm & $m$ \\
\hline 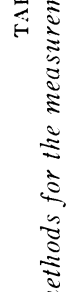 & 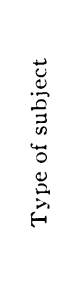 & 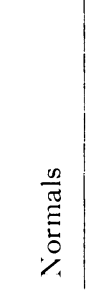 & $\begin{array}{l}\frac{n}{\pi} \\
\stackrel{\Xi}{\Xi} \\
\vdots \\
Z\end{array}$ & 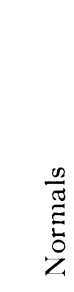 & 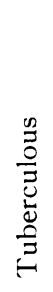 & 莡 & 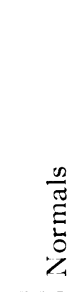 & $\begin{array}{c}\frac{n}{\pi} \\
\stackrel{0}{\Xi} \\
\vdots \\
\ddots\end{array}$ & $\begin{array}{l}\stackrel{n}{\tilde{J}} \\
\stackrel{\Xi}{\Xi} \\
\ddots\end{array}$ & 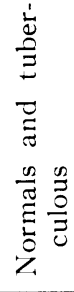 & $\begin{array}{l}\stackrel{\infty}{\Xi} \\
\frac{\Xi}{\tilde{\Xi}} \\
\frac{\delta}{z}\end{array}$ & 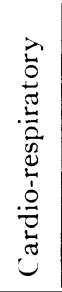 & 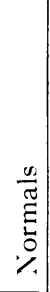 \\
\hline 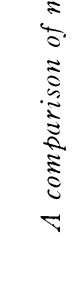 & 䒿 & 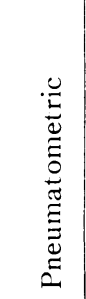 & $\begin{array}{l}0 \\
0 \\
0 \\
0 \\
\frac{1}{4} \\
0\end{array}$ & 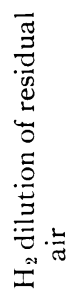 & $\begin{array}{l}0 \\
0 \\
0 \\
\frac{1}{0} \\
\frac{1}{4}\end{array}$ & 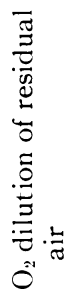 & $\begin{array}{l}0 \\
\frac{0}{\sigma} \\
\frac{0}{4}\end{array}$ & $\begin{array}{l}0 \\
3 \\
0 \\
0 \\
0 \\
0 \\
1\end{array}$ & 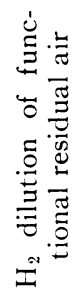 & 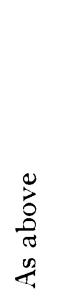 & \multicolumn{3}{|c|}{ 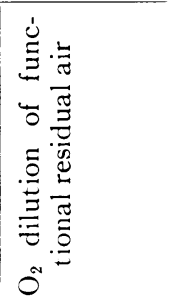 } \\
\hline & 总 & 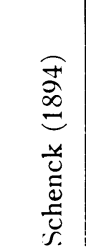 & 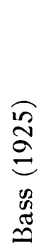 & 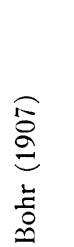 & 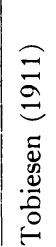 & 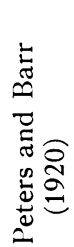 & 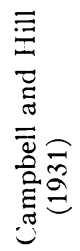 & 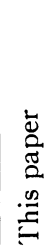 & 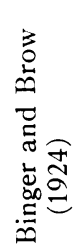 & 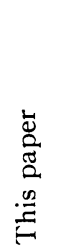 & \multicolumn{3}{|l|}{ 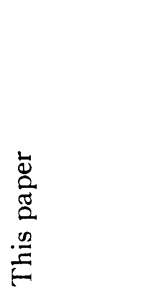 } \\
\hline
\end{tabular}


be calculated. Modifications of this method have been described by Neupaur (1879), Kochs (1884), Schenck (1894 (2), 1895 (2)), Bass (1925) and Wolf $(1928(3))$, which give figures for the residual air ranging from 400 cc. to 19,800 cc. Bass and Schenck are the only authors who give the data necessary for an estimate of how accurately observations can be duplicated on one individual (Table II). Bass himself does not discuss the accuracy of the method from this point of view and does not deny the discarding of results which show any marked deviation from the mean. From the context of his paper and results given, we suspect this to be the case.

The fallacies and drawbacks of the method are obvious. As Schenck (1894) has shown, and as we would expect, the gases in the gastro-intestinal tract are measured with the residual air. Also, the slightest leak around the mouthpiece, while the subject is making the expiratory effort, would not be shown on the tracings and yet would completely vitiate the results. The apparatus is cumbersome and its management full of technical difficulties, while more cooperation is demanded of the subject than can be given by even the most healthy individuals (Kochs (1884)).

\section{GAS DILUTION WITH FORCED BREATHING}

(a) Hydrogen Dilution

Originally described by Davy (1800) and since modified on minor points of technique by Gréhant (1887), Berenstein (1891), Bohr (1907), Hasselbach (1908 (2) and 1912), Rubow (1908), Morawitz and Siebeck (1909), Bittorf and Forschbach (1910), Siebeck (1910 and 1912), Bruns (1910) and Tobiesen (1911), this method is based on the dilution of a known volume of hydrogen by the residual air in the lungs. After a forced expiration to expel the reserve air the subject takes from 5 to 7 deep and rapid breaths from a bag or spirometer containing a known volume of hydrogen. A homogeneous mixture of gases is then assumed to be present throughout the bag or spirometer and the lungs. A sample of this mixture is analysed to find the degree to which the hydrogen has been diluted. From the degree of dilution the volume of residual air can be calculated.

\section{(b) Oxygen dilution}

Exactly the same as the hydrogen dilution method in principle, the residual air is calculated from the degree to which the nitrogen in the alveolar air is diluted by a known volume of oxygen. This method was originally developed by Durig (1903) and since by Lundsgaard and Van Slyke (1918), Peters and Barr (1920), Lundsgaard and Schierbeck (1922 and 1923), Lundsgaard (1923) and Campbell and Hill (1931).

In only four of the articles referred to is there sufficient data to form any estimate of the accuracy of either of these methods. With the exception of that by Peters and Barr, which will be discussed later, a 
considerable range of variation in duplicate analyses on the same individual is shown amounting to an average deviation from the mean of from $80 \mathrm{cc}$. to $174 \mathrm{cc}$. and a maximum deviation from the mean of from $184 \mathrm{cc}$. to $325 \mathrm{cc}$. (See Table II.) Using the oxygen dilution method as described by Lundsgaard and Van Slyke (1918) we have performed a series of 15 estimations of the residual air on one subject. The results (Table II) show a range of from $2363 \mathrm{cc}$. to $2008 \mathrm{cc}$. with an average deviation from the mean of $83 \mathrm{cc}$. and this in spite of the fact that the subject was an intelligent, healthy technician, long accustomed to vital capacity measurements and the Haldane Priestley method of sampling alveolar air. The volume of $\mathrm{O}_{2}$ was measured to $\pm 2 \mathrm{cc}$. and the $\mathrm{O}_{2}$ analyses done in duplicate with an accuracy of \pm .05 per cent; a combination of sufficient accuracy to measure the volume of a model lung to within $\pm 10 \mathrm{cc}$. (Table II).

On analysing various points of technique in the method and some of the assumptions made, it becomes obvious that a considerable range of error is to be expected in either of these two gas dilution methods. Considering the wide use that has been made of these methods and their comparatively recent popularity, it might be well to discuss our criticisms in detail.

(a) True but fortuitous variations in the residual air. The inconstancy of the reserve air has already been described and it has been shown that even under carefully controlled conditions variations in this quantity may reflect changes in the residual air which are fortuitous in nature. Indeed we think it probable that this inconstancy of the reserve air is mainly responsible for the variations found in the residual air of normal individuals, as measured by this method. A comparison of Tables I and II certainly shows a very similar deviation from the mean.

(b) Mixing of gases by forced breathing. Owing to the popularity of gas absorption methods in the estimation of the circulation rate, the problem of gas mixing in the lungs has received considerable attention. Without going fully into the controversy it may be stated that the consensus of opinion inclines to the view that in the healthy subject 5 breaths of 2 liters depth or more from a bag containing from 2 to 3 liters of a foreign gas are sufficient to ensure homogeneity throughout the lung-bag system (Krogh and Lindhard (1917), Lundsgaard (1923), Grollman and Marshall (1928), etc.). In any pathological condition, however, where there is an impairment of alveolar ventilation or reduction of vital capacity, the evidence is entirely against complete mixing of gases or any homogeneity throughout the lung-bag system (Siebeck (1910, 1911 (2), and 1912), Bruns (1910), Weiss (1928), Anthony (1930)). In spite of these observations, both these $\mathrm{H}_{2}$ and $\mathrm{O}_{2}$ dilution methods for the measurement of residual air have been used on patients with all types of pulmonary impairment, in some of which the vital capacity was admit- 
tedly below a liter. One such is the publication by Peters and Barr, whose duplicate analyses are summarised in Table II. All the criticisms we have to make regarding these gas dilution methods apply both to the methods and to the patients they used. It must be added that they make no statement as to the accuracy of the method and on that score may have discarded results showing any marked deviation from the mean, in which case our tabulation of their results in Table II is meaningless. In any case it is yet to be shown that measurements of this type on patients with such a low vital capacity have any real relationship to the residual air.

(c) Inconstancy of percentage of nitrogen in alveolar air. In the oxygen dilution method it is necessary either to measure or to assume some constant for the percentage of nitrogen in alveolar air since it is this that is being diluted with the $\mathrm{O}_{2}$ (even the respiratory dead space will contain alveolar air after expulsion of the reserve air). Various constants have been assumed for this value but actually the alveolar nitrogen shows considerable variation among different groups of patients and in individuals of the same group. In fifty-three observations on four normal individuals we have found an average of 80.28 per cent $\mathrm{N}_{2}$ in the alveolar air, in thirty-eight observations on eighteen cases with cardiorespiratory disease an average of 79.98 per cent $\mathrm{N}_{2}$, and in fourteen observations on six cases with emphysema an average of 81.21 per cent $\mathrm{N}_{2}$. Even these average values show considerable variations between the different groups but when we take the extremes we find a maximum of 82.33 per cent $\mathrm{N}_{2}$ in the alveolar air of a case of emphysema with extreme cyanosis and a minimum of 79.42 per cent $\mathrm{N}_{2}$ in a case of congenital stenosis of the pulmonary artery. In both these cases the $\mathrm{pCO}_{2}$ as calculated from analysis of the arterial blood closely agreed with that found in the alveolar air, so we can accept these extreme variations as being real and not due to faulty sampling.

(d) Gas absorbed by blood. It is known that hyperventilation produces very definite changes on the circulatory system and on haemorespiratory exchange (Marshall and Grollman (1928), Schneider (1930), Herxheimer and Kost (1931)). Any change in the circulation rate through the lungs must obviously be associated with changes in $\mathrm{O}_{2}$ consumption and also in the amount of a foreign gas which will enter into solution in the blood. To estimate the significance of these factors we have performed some experiments on a subject on whom we had made 15 determinations of the residual air by the $\mathrm{O}_{2}$ dilution method of Lundsgaard and Van Slyke (Table II). We found that during a 20 second period of hyperventilation, with 5 breaths of between 3.3 and 3.6 liters, the circulation rate ranged from 6.5 to 9.8 liters a minute, with an average of 7.8 liters in 4 observations, representing an increase of 90 per cent over his resting circulation rate. (Details of the method used have not yet been pub- 
lished.) With this was found an increase of from 59 per cent to 98 per cent in the oxygen consumption with an average of 73 per cent. The average basal oxygen consumption was $270 \mathrm{cc}$. per minute and from these figures we can calculate that the respiratory gymnastics associated with this method of measuring the residual air was accompanied by an oxygen consumption of approximately $160 \mathrm{cc}$. in 20 seconds, the actual amount varying somewhat within the degree of hyperventilation. If we add to this $10 \mathrm{cc}$. as representing the amount of $\mathrm{O}_{2}$ taken up in physical solution at $\frac{1}{2}$ an atmosphere pressure of $\mathrm{O}_{2}$, we have a total of $170 \mathrm{cc}$. of $\mathrm{O}_{2}$ which has passed into the blood during 20 seconds of hyperventilation. If an equal amount of $\mathrm{CO}_{2}$ be excreted during this period, no error in the estimation of lung volume will result. Unfortunately this is not the case. The percentage of oxygen in the bag is sufficient to ensure complete saturation of the blood but since the percentage of carbon dioxide in the inspired air is continuously rising, some impairment of $\mathrm{CO}_{2}$ excretion must occur which would tend to lower the respiratory quotient. The hyperaeration of the alveoli on the other hand would tend to raise the respiratory quotient. The exact balance of these two factors is difficult to estimate when breathing high oxygen mixtures. When room air is rebreathed under the same conditions we have found the R.Q. to average 0.92 on 5 estimations and we can only say that with high oxygen mixtures it must be considerably lower. Even an R.Q. of 0.8 would lead to an error of $34 \mathrm{cc}$. in the estimated lung volume under the circumstances described.

With the $\mathrm{H}_{2}$ dilution method the error involved by gas absorption is small but is still present. If we assume that $2000 \mathrm{cc}$. of blood passes through the lungs during the period of hyperventilation approximately $15 \mathrm{cc}$. of $\mathrm{H}_{2}$ will be absorbed at a pressure of $\frac{1}{2}$ an atmosphere representing an error of less than $20 \mathrm{cc}$., with a final dilution to 50 per cent $\mathrm{H}_{2}$.

(e) Nitrogen excretion from the blood. In the $\mathrm{H}_{2}$ dilution method, the $\mathrm{N}_{2}$ excreted is of no moment but in the $\mathrm{O}_{2}$ method, where dilution of the alveolar air is the basis of calculation, all $\mathrm{N}_{2}$ excreted will be measured as if it were originally present in the alveolar air. From the figures of Hill, Long and Lupton (1924), and of Campbell and Hill (1931), the $\mathrm{N}_{2}$ excreted in 20 seconds with hyperventilation and $\frac{1}{2}$ an atmosphere of $\mathrm{O}_{2}$ would only amount to some 10 or $12 \mathrm{cc}$., which would result in an error of less than $20 \mathrm{cc}$. in the residual air estimation.

\section{GAS DILUTION WITHOUT FORCED BREATHING}

\section{(a) Hydrogen dilution}

A very definite advance in the technique of lung volume measurement was made when Van Slyke and Binger (1923) described their method for the estimation of the residual air, or functional residual air, without forced breathing, and it is remarkable how few have availed themselves 
of this excellent method or its modification by Binger and Brow (1924). The method is based on the mixing of a known volume of hydrogen with the nitrogen in the lungs, mixing being accomplished by quiet respirations from a spirometer for from 5 to 7 minutes. The volume of air in the lungs at the moment the patient is switched to the spirometer is calculated from the volume of hydrogen originally added to the spirometer and the ratio of the percentage of hydrogen after mixing has been accomplished. Those who have worked with the method have found it entirely satisfactory (Binger (1923), Binger and Brow (1924), Meakins and Christie (1929), and Anthony (1930)), but unfortunately only one of these papers contains the data necessary for an estimate of the accuracy of the method when applied to the human subject. Meakins and Christie have used this method on a limited number of subjects with satisfactory but less impressive results than those obtained by Binger and Brow (Table II). It must be stated, however, that our own figures were obtained with the use of a Haldane gas analysis machine, using the micro method, and part at least of the variation found by us may have been caused by errors in analysis. Anthony (1930), although no protocols are published, finds with this method a maximum variation of $100 \mathrm{cc}$. and an average variation from the mean of $50 \mathrm{cc}$.

From a technical point of view the only criticisms of this method we can offer are the errors from absorption of hydrogen and excretion of nitrogen by the blood, but with similar technique it seems improbable that these factors should vary greatly from time to time in the same subject. With a final mixture of 30 per cent $\mathrm{N}_{2}$ it can be estimated from the figures of Hill, Long and Lupton (1924) and Campbell and Hill (1931) that at least $65 \mathrm{cc}$. of $\mathrm{N}_{2}$ are excreted into the lungs in 5 minutes. No figures for the absorption of hydrogen are available but if we take the absorption coefficient of hydrogen as 0.01644 and the final percentage as 30 , and assume gaseous equilibrium to have been established between the alveolar air and 10 liters of body fluids (an amount which is probably too low), it can be calculated that approximately $50 \mathrm{cc}$. of hydrogen have been absorbed from the lungs. If $1500 \mathrm{cc}$. of $\mathrm{H}_{2}$ were originally added to the spirometer and $1500 \mathrm{cc}$. of $\mathrm{N}_{2}$ were present in the alveolar air, this haemorespiratory exchange would result in a measured $\frac{\mathrm{N}_{2}}{\mathrm{H}_{2}}$ ratio of 1.07 instead of the true ratio of 1.00. The resultant error in the lung volume estimation would amount to $105 \mathrm{cc}$., a figure very close to that assumed by Anthony (1930) but a figure which, in our opinion, is minimal, $150 \mathrm{cc}$. or $200 \mathrm{cc}$. being equally probable. Again a figure for the percentage of nitrogen in the alveolar air has to be assumed and a certain error will result. In the extreme case of emphysema quoted above with an alveolar $\mathrm{N}_{2}$ of 82.33 per cent this error would amount to some $60 \mathrm{cc}$. even if the residual air were normal and not increased, as was the case. Mixing of gases throughout the lung-spirometer system, on the other hand, has been shown to be 
complete, both in normals and in those with cardiovascular disease (Van Slyke and Binger (1923)).

The main drawback of this method is one that appeals perhaps to the less scientific and more imaginative members of the medical profession. The routine use of an explosive mixture in respiratory experiments is considered by some to be unsafe and to my knowledge has frightened several investigators from the method. The possibility of arsenical poisoning must also be excluded. In a laboratory with careful workers we do not see that there is any danger, but have also found it difficult to convince both the laity and some of the medical profession. It was mainly for this reason, but also in the hope that we might be able to simplify the technique of lung volume measurement, that we have developed a method which requires little but what is available in every well-equipped hospital laboratory.

\section{(b) Oxygen dilution without forced breathing}

The principle underlying the method is again the dilution of the nitrogen in the lungs with a known volume of oxygen, but complete mixing is ensured by adopting the technique of Van Slyke and Binger. At the same time some of the drawbacks of their method are avoided.

\section{DETAILS OF THE APPARATUS}

The spirometer is of the standard type as commonly used in the estimation of the basal metabolic rate, with a capacity of from 6.5 to 8 liters (preferably the latter) and equipped with the usual ink recording attachment and thermometer. The counterpoise is adjusted so that balance is perfect with the bell at half capacity. The soda lime scrubber should be removed from the body of the spirometer and this space filled with solid paraffin to form a solid central core pierced by the inspiratory and expiratory tubes. The spirometer dead space is then reduced to a minimum, as when the bell is lowered its interior is almost completely occupied by the solid centre core, the thermometer projecting into either the inspiratory or expiratory tube. The inspiratory and expiratory valves are placed outside the spirometer and as near to the mouthpiece as is convenient. Between each valve and the spirometer is placed a 3 -way tap so that in the one position the subject breathes to and from the room, and in the other, to and from the spirometer. A soda lime scrubber is inserted on the expiratory side of the circuit between the 3 -way tap and the spirometer. Between the scrubber and the spirometer is the usual side tap for the collection of samples. With the bell fully lowered the volume of air in the whole circuit, from mouthpiece to spirometer and spirometer to mouthpiece, should not exceed 3,000 cc. or at the most 3,500 cc. (see measurement of spirometer dead space) and this quantity should be kept absolutely constant. All tubing connecting the mouthpiece with the spirometer should be of such rigidity and so arranged that the volume of its lumen will remain constant. We have found short lengths of glass tubing connected with rubber tubing very satisfactory. The volume of soda lime in the scrubber is kept constant by weighing. It is also important that there should be no variation of the level of water in the water seal. This is easily avoided by the use of a small syphon manometer so placed that it will not interfere with movements of the spirometer bell. 
Gas analysis may be accomplished by any of the many methods capable of analysing up to 50 per cent oxygen mixtures with an accuracy of \pm 0.1 per cent or less. A Haldane gas analysis machine graduated to the $5 \mathrm{cc}$. mark has been found satisfactory although the absorption of oxygen is somewhat tedious. We have collected the samples over mercury in a Haldane sampling tube, and analyses have always been done in duplicate.

\section{Measurement of spirometer dead space}

With such a complicated system it is impossible to obtain any accurate calculation of the volume of air in the spirometer dead space (i.e., the volume of air in the spirometer and tubing with the bell empty) by simple linear measurements. Much more accurate is its measurement by gas dilution, which serves the double purpose of giving a figure for this quantity, and also of standardizing the accuracy of the gas analysis and other points of technique. We have found the following technique for the measurement of the dead space simple, and surprisingly accurate. A rubber bag of from 2 to 6 liters capacity and with an air opening at both ends (such as is commonly used in the administration of gas anesthetics) is equipped with two glass stopcocks, one at either opening. One of these taps (Tap A) is connected to the mouthpiece by a short piece of rubber tubing, so that when open, the bag is in direct communication with the spirometer. The other tap (Tap B) leaves the bag open or closed to the atmosphere. With Tap A closed and the spirometer empty (having been previously thoroughly flushed through with room air), the 3-way taps are so turned that the airways are open from mouthpiece to spirometer. The rubber bag is completely evacuated by suction and Tap B closed. A carefully measured volume of oxygen is then run into the spirometer, Tap A opened, and by using the spirometer bell as a pump the gases in the circuit are thoroughly mixed. A sample is then taken from the spirometer and the oxygen percentage determined. The volume of the spirometer dead space is then calculated as follows:

or

$$
x \frac{79.1}{100}=(x+a) \frac{y}{100}
$$

$$
x=\frac{a y}{79.1-y}
$$

where $x=$ the volume of the dead space in cc.,

$y=$ the percentage of nitrogen in the sample taken after mixing is complete,

$a=$ the amount of oxygen introduced into the spirometer in cc.

Duplicate measurements show a very close agreement. Five measurements made on the spirometer circuit described above, and 5 on a standard basal metabolic rate machine, gave an average deviation from the mean of $7 \mathrm{cc}$. and a maximum deviation of $10 \mathrm{cc}$. (Table II, "Model Lung").

\section{The measurement of the functional residual air}

The spirometer circuit is thoroughly flushed with room air using the bell as a pump. Our routine has been 3 series of 4 to 5 liter excursions of the bell with an interval of 2 to 3 minutes between each to allow for diffusion of oxygen from the soda lime and other parts of the circuit. The spirometer bell is then emptied and the two 3-way taps turned so that the mouthpiece leads to the 
room air. A carefully measured volume of $\mathrm{O}_{2}$ is run into the spirometer (we have found it more accurate to measure this volume of oxygen from a tracing taken with the pen attachment than from direct observation of the scale), three minutes being allowed for temperature equilibrium to be reached, and a thermometer reading is taken. The subject who has been lying in the dorsal decubitus with the arms by the side, shoulders resting on the bed, and one pillow supporting the head, for at least 15 minutes, is then attached to the apparatus by means of the usual rubber mouthpiece and nose-clip. $\mathrm{He}$ breathes room air for 2 minutes, the drum is started and the subject is then suddenly switched to the spirometer by turning both 3-way taps simultaneously, preferably at some point during the respiratory cycle near the height of inspiration. After a period of seven minutes' quiet breathing, the 3-way taps are again turned, disconnecting the patient from the spirometer. A weight is placed on the bell of the spirometer, and left for three minutes during which time any leak will show itself. The small tap for the collection of samples is opened and from 2 to 3 liters of gas allowed to escape. A sample of the air in the spirometer can then be collected for analysis. The following practical details are essential if accurate results are to be expected. If the subject is unaccustomed to breathing from a spirometer practice should be given prior to the experiment. The subject should be unaware of the purpose of the experiment, as any conscious effort to maintain an even resting respiratory level usually results in hopeless irregularities. It has been our custom to inform the subject that it is just a "breathing test," that he will feel nothing, need only breathe quietly and can go to sleep if he wants to. Leaks around the mouthpiece should be carefully avoided. It has been our custom to moisten the mouthpiece with water or dilute glycerin and observe the mouth throughout the experiment. Resistance to respiration should be minimal and any change in resistance, such as is easily produced by sticking of the rubber valves, should be carefully avoided. The influence of resistance on the resting respiratory level has already been mentioned. In one of our normal subjects we have found that a slight increase in the expiratory resistance, although insufficient to affect the respiratory rhythm, raised the functional residual air from an average of $2425 \mathrm{cc}$. in 15 estimations to an average of $2750 \mathrm{cc}$. in 5 estimations. For these reasons the respiratory valves should be examined daily for any stickiness of the valve flaps. The efficiency of the soda lime scrubber should be checked at regular intervals by analysing the spirometer air for $\mathrm{CO}_{2}$; if this rises above 0.2 per cent the soda lime should be changed.

\section{CALCULATION}

The actual volume measured by this method is obviously the amount of air in the lungs at the moment the patient is switched to the spirometer. The nitrogen in the lungs at this moment is diluted by a known volume of oxygen, and from the degree of dilution the lung volume can be calculated from the equation,

$$
x \frac{v}{100}+d \frac{79.1}{100}=(x+d+a-b) \frac{y}{100},
$$

where $x=$ the lung volume in cc.,

$v=$ percentage of $\mathrm{N}_{2}$ in lungs at beginning of experiment,

$y=$ percentage of $\mathrm{N}_{2}$ in the circuit at end of experiment,

$a=$ oxygen in spirometer at beginning of experiment in cc.,

$b=$ oxygen absorbed during experiment in cc.,

$d=$ dead space in spirometer circuit in cc. 
Unfortunately for the utility of this equation the value of $v$ has been shown to be by no means a constant and is not measured in each subject. Also, there is no justification for the assumption that at the end of the experiment there is any homogeneity throughout the lung spirometer system. Indeed it is only reasonable to suppose that, at the time the sample is taken, the nitrogen in the inspired air (i.e., the nitrogen in the spirometer) is of lower percentage than the nitrogen in the alveoli, since more oxygen is being absorbed than $\mathrm{CO}_{2}$ excreted, and therefore a process of $\mathrm{N}_{2}$ concentration is continuously taking place in the lungs. However, the rise in the percentage of $\mathrm{N}_{2}$, which takes place when air is inhaled from the spirometer, must be equivalent to the rise which takes place when air is inhaled from the room, since in both the lungs are performing the same process of $\mathrm{N}_{2}$ concentration. Applying these theoretical considerations to our technique of lung volume measurement, it is clear that if we use $v$ (the alveolar $\mathrm{N}_{2}$ percentage at the beginning of the experiment) to represent the amount of $\mathrm{N}_{2}$ being diluted, the sample $y$ (the percentage of $\mathrm{N}_{2}$ in the circuit after mixing is complete) must also be taken from the alveolar air. But since the difference between $v$ and the room air nitrogen is equivalent to the difference between $y$ taken from the alveoli and $y$ taken from the spirometer, we are perfectly justified in substituting the room air nitrogen (79.1 per cent) for $\boldsymbol{v}$, if the sample from which $y$ is estimated is taken from the spirometer.

Our equation will then simplify itself to

or

$$
x \frac{79.1}{100}+d \frac{79.1}{100}=(x+d+a-b) \frac{y}{100}
$$

$$
x=\frac{y(a-b)}{79.1-y}-d,
$$

the meaning of $x, a, b$ and $d$ remaining unchanged but $y$ signifying the percentage of nitrogen in the spirometer at the end of the experiment. In this way those errors accruing from the inconstancy of the alveolar nitrogen are made to compensate for the lack of homogeneity throughout the lung spirometer system after so-called mixing has been completed. Actually it can be shown that compensation for these errors is not quite complete. If room air be inspired and $7 \mathrm{cc}$. per cent of $\mathrm{O}_{2}$ are absorbed, and $6 \mathrm{cc}$. per cent of $\mathrm{CO}_{2}$ excreted, then the percentage of $\mathrm{N}_{2}$ will rise from 79.1 in the inspired air to 79.9 in the expired air, a rise of 0.8 per cent. If the oxygen of the inspired air be raised to 45 per cent, then with the same metabolic factors the percentage of $\mathrm{N}_{2}$ will be raised from 55 to 55.6 , a rise of 0.6 per cent. Since the respiratory dead space is a constant factor throughout, these differences between the inspired and expired nitrogen are exactly proportional to the differences between inspired and alveolar nitrogen. As shown, this difference does vary somewhat with the percentage of nitrogen inspired, the change when breathing 55 per cent $\mathrm{N}_{2}$ amounting to only 75 per cent of that when breathing room air. This discrepancy has to be disregarded in our calculations, but the error involved is a small one, amounting to some 10 to $20 \mathrm{cc}$. in the functional residual air of an average subject.

As already stated, we have found that a more accurate measurement of the amount of oxygen added to the spirometer is obtained by graphic registration than by a direct reading on the scale. The oxygen absorbed is measured in the usual way by a line drawn through the resting respiratory level. Difficulties in the measurement of this quantity are discussed below.

The actual volume measured by the above technique and by the use of 
formula (2) is the amount of air in the lungs at the moment the subject was switched from breathing room air to the spirometer. The height of this point above the resting respiratory level is measured from the respiratory tracing. To obtain the value of the functional residual air, this amount is subtracted from $x$. The quantity so obtained represents the volume of the residual air at the temperature of the spirometer air. This must be corrected to $37^{\circ} \mathrm{C}$. saturated with water vapor. It has been the custom of some to correct also for the barometric pressure but it has yet to be shown that the barometric pressure has any influence on lung volume.

To allow for nitrogen excretion we have estimated from the figures of Hill, Long and Lupton (1924) and Campbell and Hill (1931) that approximately 65 cc. of nitrogen will be excreted in 7 minutes when breathing an atmosphere of 44 per cent oxygen. We have therefore subtracted $80 \mathrm{cc}$. in all cases from the measured functional residual air. Obviously no correction need be made for oxygen passing into solution, as this will be registered as oxygen consumption

From the functional residual air, the total capacity and residual air can be calculated by adding the complemental and subtracting the reserve air respectively. It has been our custom to measure these immediately after the lung volume estimation and with the subject in the same carefully controlled position. ${ }^{2}$

\section{CRITICISM}

In our opinion the main drawback to this method is the difficulty in obtaining an accurate estimation of the oxygen consumption on some subjects. However, one can always tell from a 7 minute respiratory tracing approximately how much room there is for error. Our routine has been to draw the base line, which we think represents the oxygen consumption, and if one has to admit the possibility of more than a $50 \mathrm{cc}$. error in the total oxygen consumed the experiment is discarded or, if a better tracing is not procurable, the possible range of error is noted. With a final mixture of 45 per cent oxygen, an error of $50 \mathrm{cc}$. in the oxygen consumption will lead to an error of $93 \mathrm{cc}$. in the lung volume. The only other criterion for the discarding of an experiment has been the possibility of a leak as shown by the spirometer tracing.

Nitrogen excretion probably varies somewhat from patient to patient

${ }^{2}$ Sendroy, Hiller and Van Slyke (1932) have recently published a method for the determination of lung volume by respiration of oxygen without forced breathing. In their method it is essential that "at the end of the period the subject brings his lungs to the same position as at the beginning." They have only used this method for the estimation of the residual air but when we consider the fluctuation of the reserve air described above it becomes evident that expert cooperation is necessary, and accurate results can hardly be expected from patients with any impairment of respiratory function. The authors do not describe any measurements of the functional residual air, and we hardly think that this would be feasible with their method. We have always found that any such voluntary control of the resting respiratory level even in trained individuals leads to marked irregularities. 
but we cannot believe that with similar experimental technique this quantity can vary by more than 10 or $20 \mathrm{cc}$. representing a final error of from 15 to $25 \mathrm{cc}$.

The question of mixing throughout the lung-spirometer circuit cannot be so satisfactorily approached by this method as by the method of Van Slyke and Binger (1923), since the nitrogen percentage is falling at an increasing rate throughout the experiment, and since the sample taken must represent the air in the spirometer bell. Van Slyke and Binger have conclusively shown that both in cardiacs and in normal subjects the technique we have used is sufficient to ensure mixing in 5 minutes. To make doubly sure we have extended this time to 7 minutes.

In 25 measurements of the functional residual air in 3 normal subjects we have found an average deviation from the mean of each subject of 93 cc., and a maximum deviation of $170 \mathrm{cc}$. In 40 measurements on 14 subjects with cardio-respiratory disease, ranging from advanced emphysema to spontaneous pneumothorax, we have found an average deviation from the mean of each subject of $107 \mathrm{cc}$. and a maximum deviation of 280 cc. When these results are compared with those by other methods (Table II) it must be remembered that at least in some instances in this group results showing marked deviation from the mean have been discarded. Moreover, only this method and the method of Van Slyke and Binger can be used with any justification in those cases where there is any marked impairment of vital capacity or pulmonary ventilation. In this type of case our method may or may not be as accurate as the method of Van Slyke and Binger, but in its simplicity and applicability to clinical use it certainly presents some advantages.

\section{SUMMARY AND CONCLUSION}

(a) A simple classification of the subdivisions of the total lung volume is proposed.

(b) The complemental, reserve and residual airs can show considerable variations which are purely fortuitous in nature, even under carefully controlled conditions on one individual. Similar variations could not be demonstrated in the functional residual air.

(c) The methods for the determination of the residual and functional residual air are reviewed, and experimental evidence given to show that most of these will give fallacious results in both normal and abnormal individuals.

(d) A simple method is described for the measurement of the functional residual air.

\section{BIBLIOGRAPHY}

Anthony, A., Beitr. z. Klinik d. Tuberk., 1927, lxvii, 711. Zur Methode der Spirometrie. Deutsches Arch. f. klin. Med., 1930, clxvii, 129. Untersuchungen über Lungenvolumina und Lungenventilation. 
Bass, E., Ztschr. f. d. ges. exp. Med., 1925, xlvi, 46. Zur Methodik der Residualluftbestimmung.

Berenstein, M., Arch. f. Physiol., 1891, 1, 363. Neue Versuche zur Bestimmung der Residualluft am lebenden Menschen.

Binger, C. A. L., and Brow, G. R., J. Exper. Med., 1924, xxxix, 677. Studies on the Respiratory Mechanism in Lobar Pneumonia; A Study of Lung Volume in Relation to the Clinical Course of the Disease.

Binger, C. A. L., J. Exper. Med., 1923, xxxviii, 445. The Lung Volume in Heart Disease.

Bittorf, A., and Forschbach, J., Ztschr. f. klin. Med., 1910, 1xx, $474 . \quad$ Untersuchungen über die Lungenfüllung bei Krankheiten.

Bohr, C.., Deutsches Arch. f. klin. Med., 1907, lxxxviii, 385. Die funktionellen Änderungen in der Mittellage und Vitalkapazität der Lungen.

Bruns, O., Med. Klin., 1910, vi, Band II, 1524. Die Bedeutung der spirometrischen Untersuchung von Emphysematikern und Herzkranken.

Campbell, J. A., and Hill, L., J. Physiol., 1931, lxxi, 309. Concerning the Amount of Nitrogen Gas in the Tissues and its Removal by Breathing Almost Pure Oxygen.

Davy, H., Researches Concerning Nitrous Oxide. London, Johnson, 1800.

Durig, A., Zentralbl. f. Physiol., 1903, xvii, 258. Über die Grösse der Residualluft.

Gréhant, N., Compt. rend. Soc. de biol., 1887, Sér. 8, iv, $242 . \quad$ Perfectionnement du procédé de mesure du volume des poumons par l'hydrogène.

Grollman, A., and Marshall, E. K., Jr., Am. J. Physiol., 1928, lxxxvi, 110. The Time Necessary for Rebreathing in a Lung-Bag System to Attain Homogeneous Mixture.

Hasselbach, K. A., Deutsches Arch. f. klin. Med., 1908, xciii, 53. Über die Einwirkung der Temperatur auf die vitale Mittellage der Lungen. Deutsches Arch. f. klin. Med., 1908, xciii, 64. Über die Totalkapazität der Lungen. Deutsches Arch. f. klin. Med., 1912, cv, 440. Chemische Atmungsregulation und Mittelkapazität der Lungen.

Herxheimer, H., and Kost, R., Ztschr. f. klin. Med., 1931, cxvi, 88. Untersuchungen über den Gasstoffwechsel bei verschiedenen Arten der Hyperventilation.

Hill, A. V., Long, C. N. H., and Lupton, H., Proc. Roy. Soc., B, 1924, xcvii, 84. Muscular Exercise, Lactic Acid and the Supply and Utilisation of Oxygen-Parts IV-VI.

Hutchinson, J., Lancet, 1846, i, 630. On the Capacity of the Lungs, and on the Respiratory Movements, with the View of Establishing a Precise and Easy Method of Detecting Disease by the Spirometer.

Kochs, W., Ztschr. f. klin. Med., 1884, vii, 487. Ueber eine neue Bestimmungsweise der Grösse der Residualluft beim Lebenden Menschen.

Krogh, A., and Lindhard, J., J. Physiol., 1917, li, 59. The Volume of the Dead Space in Breathing and the Mixing of Gases in the Lungs of Man.

Livingstone, J. L., Lancet, 1928, i, 754. Variations in the Volume of the Chest with Changes of Posture.

Lundsgaard, C., J. Am. Med. Assoc., 1923, lxxx, 163. Determination and Interpretation of Changes in Lung Volumes in Certain Heart Lesions.

Lundsgaard, C., and Schierbeck, K., Proc. Soc. Exper. Biol. and Med., 1922, xx, 151-167. Studies on Lung Volume. IV. Investigations on Admixture of Air in the Lungs with Other Air. Acta med. Scandinav., 1923, lviii, 470, 486, 495 and 541. Untersuchungen über die Volumina der Lungen. I-IV. 
Lundsgaard, C., and Van Slyke, D. D., J. Exper. Med., 1918, xxvii, 65. Studies on Lung Volume. I. Relation between Thorax Size and Lung Volume in Normal Adults.

Marshall, E. K., Jr., and Grollman, A., Am. J. Physiol,, 1928, Ixxxvi, 117. A Method for the Determination of the Circulatory Minute Volume in Man.

Meakins, J. C., and Christie, R. V., Ann. Int. Med., 1929, iii, 423. Lung Volume and its Variations.

Morawitz, P., and Siebeck, R., Deutsches Arch. f. klin. Med., 1909, xcvii, 201. Die Dyspnoe durch Stenose der Luftwege. (1) Gasanalytische Untersuchungen.

Neupaur, J., Deutsches Arch. f. klin. Med., 1879, xxiii, 481. Die physikalischen Grundlagen der Pneumatometrie und des Luftwechsels in den Lungen.

Panum, P. L., Arch. f. d. ges. Physiol., 1868, v (i), $125 . \quad$ Untersuchungen über die physiologischen Wirkungen der comprimirten Luft.

Peabody, F. W., and Sturgis, C. C., Arch. Int. Med., 1921, xxviii, 501. Clinica! Studies of the Respiration. VII. The Effect of General Weakness and Fatigue on the Vital Capacity of the Lungs.

Peters, J. P., and Barr, D. P., Am. J. Physiol., 1920, liv, 335. Studies of the Respiratory Mechanism in Cardiac Dyspnea. II. A Note on the Effective Lung Volume in Cardiac Dyspnea.

Pflüger, E., Arch. f. d. ges. Physiol., 1882, xxix, 244. Das Pneumonometer.

Rubow, V., Deutsches Arch. f. klin. Med., 1908, xcii, 255. Untersuchungen über die Atmung bei Herzkrankheiten. Ein Beitrag zum Studium der Pathologie des kleinen Kreislaufes.

Schenck, F., Arch. f. d. ges. Physiol., 1894, lv, 191. Ueber die Bestimmung der Residualluft. Arch. f. d. ges. Physiol., 1894, lviii, 233. Zur Bestimmung der Residualluft. Arch. f. d. ges. Physiol., 1895, lix, 554. Nochmals zur Bestimmung der Residualluft. Arch. f. d. ges. Physiol., 1895, lxi, 475. Beiträge zur Mechanik der Athmung.

Schneider, E. C., Am. J. Physiol., 1930, xci, 390. A Study of Respiratory and Circulatory Responses to a Voluntary Gradual Forcing of Respiration.

Sendroy, J., Jr., Hiller, A., and Van Slyke, D. D., J. Exper. Med., 1932, Iv, 361. Determination of Lung Volume by Respiration of Oxygen without Forced Breathing.

Siebeck, R., Deutsches Arch. f. klin. Med., 1910, c, 204. Über die Beeinflussung der Atemmechanik durch krankhafte Zustände des Respirationsund Kreislaufapparates. Deutsches Arch. f. klin. Med., 1911, cii, 390. Über den Gasaustauch zwischen der Aussenluft und den Alveolen. III. Die Lungenventilation beim Emphysem. Ztschr. f. Biol., 1911, lv, 267. Über den Gasaustauch zwischen der Aussenluft und den Alveolen. Deutsches Arch. f. klin. Med., 1912, cvii, 252. Die funktionelle Bedeutung der Atemmechanik und die Lungenventilation bei Kardialer Dyspnoe.

Thiel, K., Ztschr. f. d. ges. exper. Med., 1929, lxvii, 810. Über Mittellagenveränderung durch Stenosierung der oberen Luftwege.

Tobiesen, F., Skandinav. Arch. f. Physiol., 1911, xxv, 209. Spirometrische Untersuchungen an Schwindsüchtigen.

Van Slyke, D. D., and Binger, C. A. L., J. Exper. Med., 1923, xxxvii, 457. The Determination of Lung Volume without Forced Breathing.

Weiss, R., Ztschr. f. d. ges. exper. Med., 1928, 1xi, 357. Über die Durchmischungsverhältnisse in der Lunge bei der Bestimmung des zirkulatorischen Minutenvolumens. 
Wilson, W. H., J. Physiol., 1927, lxiv, 54. The Influence of Posture on the Volume of the Reserve Air.

Wolf, H. J., Ztschr. f. d. ges. exper. Med., 1928, 1xii, 217. Die nervöse Atmungsregulation bei der Lungentuberkulose. I. Das Verhalten der respiratorischen Mittellage bei Stenose, Überdruck und Unterdruck. Ztschr. f. d. ges. exper. Med., 1928, lxii, 696. Die nervöse Atmungsregulation bei Lungentuberkulose. II. Das Verhalten der Lungenvolumina. Ztschr. f. d. ges. exper. Med., 1928, lxiii, 616. Die nervöse Atmungsregulation bei der Lungentuberkulose. III. Der Einfluss des künstlichen Pneumothorax auf den Ausfall der Funktionsprüfungen der Atmung und auf das Verhalten der Lungenvolumina. 